Zeszyty Naukowe Szkoły Głównej Gospodarstwa Wiejskiego w Warszawie

Problemy Rolnictwa Światowego tom 19 (XXXIV), zeszyt 1, 2019: 37-46

DOI: 10.22630/PRS.2019.19.1.3

Antoni Faber $^{1}$, Zuzanna Jarosz ${ }^{2}$, Aleksandra Król ${ }^{3}$

Instytut Uprawy Nawożenia i Gleboznawstwa - Państwowy Instytut Badawczy

w Puławach

\title{
Wpływ zmian klimatu na efektywność wykorzystywania azotu oraz jego straty
}

\section{The Impact of Climate Change on the Efficiency of Nitrogen Use and its Losses}

\begin{abstract}
Synopsis. Celem badań było określenie przewidywanych plonów, efektywności wykorzystania N (NUE), wymywania $\mathrm{N}$, emisji $\mathrm{N}_{2} \mathrm{O}$ i $\mathrm{NH}_{3}$ w zależności od zmian klimatu do $2050 \mathrm{r}$. Badania wykonano, z zastosowaniem modelu DNDC, dla okresów lat 1991-2010, 2011-2030 i 2031-2050 oraz 10 lokalizacji w Polsce. W symulacjach uwzględniono zmianowanie roślin: kukurydza na ziarno - jęczmień jary - rzepak ozimy - pszenica ozima, które uprawiano na glebach lekkich, średnich i ciężkich, przy nawożeniu wynoszącym odpowiednio: 140, 90, 160 i $120 \mathrm{~kg} \mathrm{~N}^{-1}$. Stwierdzono, że zmiany klimatu przyczynić się mogą do wzrostów plonów kukurydzy na ziarno (6-43\%) i rzepaku ozimego (2-8\%), spadków plonów pszenicy ozimej (od -18 do $-5 \%$ ) oraz nieistotnych zmian w plonach jęczmienia jarego. NUE wzrośnie w uprawie kukurydzy (2-17\%), zmaleje w uprawach pszenicy ozimej (3-22\%) i jęczmienia jarego (3-17\%) oraz nie ulegnie zmianie $\mathrm{w}$ przypadku rzepaku ozimego. Zmiany NUE oraz straty $\mathrm{N}$ nie wpływały na konieczność zmniejszenia dawek azotu w przyszłej uprawie badanych roślin.
\end{abstract}

Słowa kluczowe: zmiany klimatu, plony, efektywność, azot, straty

Abstract. The aim of the study was to determine the expected yields, the efficiency of $\mathrm{N}$ (NUE) use, $\mathrm{N}$ leaching, $\mathrm{N}_{2} \mathrm{O}$ and $\mathrm{NH}_{3}$ emissions depending on climate change until 2050. The research was carried out using the DNDC model for the years 1991-2010, 2011-2030 and 2031-2050 as well as 10 locations in Poland. In the simulations, the crop rotation were considered: maize for grain - spring barley - winter rape winter wheat, which was grown on light, medium and heavy soils, with fertilization of, respectively: 140, 90,160 and $120 \mathrm{~kg} \mathrm{~N} \mathrm{ha}^{-1}$. It was found that climate change can contribute to increase in the yield of maize $(6-43 \%)$ and winter rape $(2-8 \%)$, decreases in winter wheat yield (from -18 to $-5 \%)$ and negligible changes in yields of spring barley. NUE will increase in the cultivation of maize (2-17\%), it will decrease in winter wheat (3-22\%) and spring barley (3-17\%) crops and will not change in the case of winter oilseed rape. NUE changes and $\mathrm{N}$ losses did not affect the need to reduce nitrogen doses in the future cultivation of the studied plants.

Key words: climate change, yield, NUE, nitrogen, losses

JEL Classification: Q15, Q53

\footnotetext{
${ }^{1}$ prof. dr hab., IUNG-PIB, ul. Czartoryskich 8, 24-100 Puławy, e-mail: faber@iung.pulawy.pl; https://orcid.org/0000-0002-3055-1968

2 dr, e-mail: zjarosz@iung.pulawy.pl; https://orcid.org/0000-0002-3428-5804

${ }^{3} \mathrm{mgr}$, e-mail: akrol@iung.pulawy.pl; https://orcid.org/0000-0002-6680-6328

Opracowanie wykonano w ramach zadania $2.6 \mathrm{w}$ programie wieloletnim IUNG-PIB.
} 


\section{Wprowadzenie}

Przyszłe zmiany temperatury, opadów, uwilgotnienia gleb mogą mieć znaczący wpływ na wykorzystywanie gruntów rolnych oraz na produkcyjność roślin uprawnych w Europie. Zagadnienie to było przedmiotem analiz w 1748 artykułach naukowych opublikowanych do 2016 roku (Knox i in., 2016). Z syntezy wybranych 41 artykułów wynika, że plony podstawowych roślin uprawnych (pszenica, jęczmień, kukurydza, ziemniak, burak cukrowy, ryż, żyto) wzrosną w Europie do 2050 roku średnio o 8\%. Wzrosty plonów będą zróżnicowane regionalnie. W Europie Środkowej, w tym w Polsce, prognozuje się wzrosty plonów: kukurydzy (o 14\%), ziemniaka i buraka cukrowego (o 17\%) oraz pszenicy (o 10\%) przy średniej zmienności plonów wynoszącej $+6 \%$ (Knox i in., 2016). Plony żyta i jęczmienia według przewidywań nie ulegną zmianom.

Prognozowane wielkości zmian plonów należy traktować jako wartości przybliżone, co wynika z niepewności scenariuszy zmian klimatu oraz faktu, że skutki zmian klimatu będą zależne od lokalnych zmienności gleb i agroklimatu, zmian w użytkowaniu gruntów oraz dostępności wody i sprzętu do nawodnień.

Badania skutków przewidywanych zmian klimatu w skali regionalnej (NUTS2; województwa w Polsce) wykazały, że uwzględniając plony ograniczone niedoborem wody oraz plony ograniczone niedoborem azotu, należy oczekiwać w Europie spadków plonów podstawowych upraw (kukurydza na ziarno, ziemniak, burak cukrowy, jęczmień ozimy, rzepak ozimy, pszenica ozima) do 2050 roku (Webber i in., 2015). W Polsce do 2050 roku można się spodziewać według cytowanych badań, spadków lub przyrostów plonów w przypadku kukurydzy od -10 do $10 \%$, rzepaku ozimego od $-20 \%$ do 0 oraz pszenicy ozimej od -5 do $10 \%$. Z badań tych wynika także, że do 2050 roku wraz ze spadkami plonów prawdopodobnie będzie zmniejszać się nawożenie azotem. Jest to wniosek bardzo istotny ze względu na mitygacje zmian klimatu, w których istotną rolę odgrywa ograniczenie strat azotu emitowanego do atmosfery $\mathrm{i}$ wód. Zagadnienie to jest ważne również $\mathrm{z}$ uwagi na rysującą się coraz wyraźniej potrzebę ograniczenia nadmiarów wprowadzanego do środowiska reaktywnego azotu, co wpływa nie tylko na zanieczyszczenie środowiska, ale również zmniejsza bioróżnorodność ekosystemów (Erisman i in., 2013, Galloway i in., 2008).

Bezproduktywne straty azotu, które przyczyniają się do pogłębienia zmian klimatu (emisje do atmosfery podtlenku azotu- $\mathrm{N}_{2} \mathrm{O}$ i amoniaku $-\mathrm{NH}_{3}$ ) i zanieczyszczenia wód (azotany) są efektem zbyt niskiej efektywności wykorzystywania azotu (NUE) ze stosowanych nawozów (EU Nitrogen Expert Panel, 2015, Billen i in., 2014, Lassaletta i in., 2014).

Celem badań było określenie dynamiki zmian plonów, efektywności wykorzystywania azotu (NUE), wymywania i spływu powierzchniowego azotu, emisji podtlenku azotu i amoniaku w zależności od prognozowanych zmian klimatu.

\section{Dane i metody}

W badaniach wykorzystano komputerowy model DNDC (wersja 9.2) (Gilhespy i in., 2014, Giltrap i in. 2010) w kalibracji opracowanej w JRC EC dla Europy (Leip i in. 2007, Leip i in. 2008). Model ten ma bogate referencje i wykorzystywany był w wielu miejscach na świecie do symulacji bilansów węgla, azotu i wody, emisji $\mathrm{CO}_{2}, \mathrm{CH}_{4}, \mathrm{~N}_{2} \mathrm{O}, \mathrm{NH}_{3}$ oraz 
sekwestracji węgla organicznego w glebach pod uprawami rolniczymi (poziom pola). Przed zastosowaniem model był rekalibrowany w IUNG-PIB.

W symulacjach wykorzystywano średnie dobowe dane meteorologiczne (temperaturę minimalną i maksymalną, opad) dla trzech okresów: 1991-2010 (S1), 2011-2030 (S2) oraz 2031-2050 (S3). Dane meteorologiczne dla lat przyszłych pochodziły z projekcji klimatycznych opracowanych na podstawie najnowszych symulacji regionalnych programu CORDEX (Coordinated Regional Climate Downscaling Experiment) dla Europy (Liszewska, 2016; nie publikowane). W symulacjach wykorzystano dane dla stacji meteorologicznych: Łódź, Okęcie, Tarnów, Chojnice, Katowice, Kielce, Lublin, Poznań, Toruń, Zielona Góra. Przyrosty median temperatury dla wszystkich stacji w okresach S2 i S3 wynosiły odpowiednio 0,93 i $1,22{ }^{\circ} \mathrm{C}$ w stosunku do $\mathrm{S} 1 \mathrm{i}$ były statystycznie istotne. Natomiast przyrosty median opadów atmosferycznych dla wszystkich stacji w okresach S2 i S3 wynosiły odpowiednio 29 i $39 \mathrm{~mm}$ w stosunku do S1 i były istotne statystycznie.

Dla wymienionych okresów i stacji meteorologicznych przeprowadzono symulacje dla roślin uprawianych w zmianowaniu: kukurydza na ziarno - jęczmień jary - rzepak ozimy pszenica ozima. Rośliny uprawiane były na glebach: lekkich (L), średnich (Ś) i ciężkich (C) w systemie uprawy uproszczonej (bez orki płużnej) z pozostawieniem na polu wszystkich resztek pożniwnych w polu kukurydzy i rzepaku. Słoma zbóż była zbierana. Pod rośliny stosowano nawożenie azotem $\mathrm{w}$ postaci mocznika lub saletry amonowej w dawkach wynoszących odpowiednio: 140, 90, 160 i $120 \mathrm{~kg} \mathrm{~N} \mathrm{ha}^{-1}$. Dawki były dzielone i stosowane zgodnie z zaleceniami nawozowymi. W bilansach azotu uwzględnione zostały: nawożenie mineralne $\mathrm{N}$, depozycja $\mathrm{N}$ oraz azot pozostający na polu z resztkami pożniwnymi.

W symulacjach założono: stężenie $\mathrm{N}$ w opadzie atmosferycznym - 2,5 ppm, stężenie amoniaku w powietrzu $-0,06 \mu \mathrm{g} / \mathrm{m}^{3}$, wzrost stężenia $\mathrm{CO}_{2} \mathrm{w}$ atmosferze według trendów NOAA znajdujący się w przedziale 350-453 ppm w okresie lat 1991-2050.

Ogółem wykonano 5760 symulacji. W niniejszym opracowaniu uwzględniono: plony roślin $\left(\mathrm{t} \mathrm{ha}^{-1}\right)$, pobranie azotu $\left(\mathrm{kg} \mathrm{ha}^{-1} \mathrm{r}^{-1}\right)$, wymycie azotu $\mathrm{z}$ gleby $\left(\mathrm{kg} \mathrm{ha}^{-1} \mathrm{r}^{-1}\right)$, spływ powierzchniowy azotu $\left(\mathrm{kg} \mathrm{ha}^{-1} \mathrm{r}^{-1}\right)$, emisję podtlenku azotu $\left(\mathrm{kg} \mathrm{N}_{2} \mathrm{O}-\mathrm{N} \mathrm{ha}^{-1} \mathrm{r}^{-1}\right)$ oraz emisje amoniaku ( $\mathrm{kg} \mathrm{NH}_{3}-\mathrm{N} \mathrm{ha}{ }^{-1} \mathrm{r}^{-1}$ ). Na podstawie pobrania azotu wyliczono efektywność wykorzystywania azotu (NUE) według wzoru:

$$
\text { NUE }(\%)=(\text { Pobranie N/Dostępny N }) * 100
$$

gdzie: dostępny $\mathrm{N}$ to suma azotu ze wszystkich źródeł (nawozy, depozycja, resztki pożniwne).

Uzyskane serie wyników $w$ latach 1991-2010 dla 10 lokalizacji stacji meteorologicznych przedstawiono jako mediany (dla każdej rośliny $\mathrm{n}=50$ ). Wyniki dla lat 2011-2030 oraz 2031-2050 oraz 10 lokalizacji stacji meteorologicznych zaprezentowano jako przyrosty lub spadki median $(\mathrm{n}=50)$, wyrażone w procentach $\mathrm{w}$ stosunku do danych z okresu 1991-2010. Istotność różnic median dla okresów S1, S2 i S3 określano z wykorzystaniem testu median według Mood'a w programie Statgraphics.

\section{Wyniki badań}

Plony główne kukurydzy na ziarno i pszenicy ozimej rosły dość dynamiczne wraz z poprawą jakości gleb (tab. 1). Dynamika przyrostów plonów jęczmienia jarego i rzepaku w zależności od gleb była niewielka. Nie stwierdzono również istotnego pogorszenia 
plonów upraw nawożonych mocznikiem w stosunku do upraw nawożonych saletrą amonową. Oznaczałoby to, że azot z mocznika stosowanego przedsiewnie i pogłównie nie ulegał na tyle wielkim stratom gazowym, aby mogło to znaleźć odzwierciedlenie w plonach. Znaczących różnic w plonach oczekiwano dlatego, że współczynniki emisji amoniaku wynoszą dla mocznika 15,9-16,8\% dawki zastosowanego azotu, a dla saletry amonowej 1,6-3,3\% (EMEP/EEA, 2016).

Tabela 1. Plony uprawianych roślin w latach 1991-2010 (S1)

Table 1. Yields of cultivated plants in the years 1991-2010 (S1)

\begin{tabular}{|c|c|c|c|c|c|c|}
\hline \multirow{3}{*}{ Uprawa } & \multicolumn{6}{|c|}{ Plon $\left(\mathrm{t} \mathrm{ha}^{-1}\right)$} \\
\hline & \multicolumn{3}{|c|}{ Mocznik } & \multicolumn{3}{|c|}{ Saletra amonowa } \\
\hline & $\mathrm{L}$ & Ś & $\mathrm{C}$ & $\mathrm{L}$ & Ś & $\mathrm{C}$ \\
\hline Kukurydza & 7,06 & 9,30 & 10,40 & 7,21 & 9,30 & 10,39 \\
\hline Jęczmień jary & 3,42 & 3,44 & 3,42 & 3,34 & 3,44 & 3,53 \\
\hline Rzepak ozimy & 2,15 & 2,24 & 2,30 & 2,13 & 2,24 & 2,32 \\
\hline Pszenica ozima & 7,75 & 8,64 & 9,01 & 7,94 & 8,66 & 9,07 \\
\hline
\end{tabular}

Źródło: badania własne.

Prognozowane zmiany klimatu przyczyniły się do istotnego statystycznie wzrostu przewidywanych plonów kukurydzy na ziarno (tab. 2). Były one największe na glebie lekkiej i stopniowo malały na glebach średnich i ciężkich. Przyrosty plonów na glebach lekkich wynosiły ponad 20\%, co sugerowały analizy metadanych (Knox i in., 2016). Na glebach średnich wynosiły ponad $10 \%$ i były zbieżne z wynikami uzyskanymi dla Europy (Webber i in., 2015). Również przyrosty na glebach ciężkich były zbliżone do wartości określonych w cytowanej literaturze. Różnice w przyrostach nie były znaczące w zależności od formy zastosowanego nawozu azotowego.

Tabela 2. Przyrosty plonów w latach 2011-2030 (S2) oraz 2031-2050 (S3)

Table 2. Yield increments in 2011-2030 (S2) and 2031-2050 (S3)

\begin{tabular}{|c|c|c|c|c|c|c|c|}
\hline \multirow{3}{*}{ Uprawa } & \multirow{3}{*}{ Scenariusz } & \multicolumn{6}{|c|}{ Przyrost plonu (\%) } \\
\hline & & \multicolumn{3}{|c|}{ Mocznik } & \multicolumn{3}{|c|}{ Saletra amonowa } \\
\hline & & $\mathrm{L}$ & Ś & $\mathrm{C}$ & $\mathrm{L}$ & Ś & $\mathrm{C}$ \\
\hline \multirow{2}{*}{ Kukurydza } & $\mathrm{S} 2$ & $34,7^{*}$ & $17,6^{*}$ & $5,6^{*}$ & $34,6^{*}$ & $16,9 *$ & $5,6^{*}$ \\
\hline & $\mathrm{S} 3$ & $42,9 *$ & $18,1^{*}$ & $5,6^{*}$ & $37,5^{*}$ & $17,9 *$ & $5,6^{*}$ \\
\hline \multirow{2}{*}{ Jęczmień jary } & $\mathrm{S} 2$ & $-6,5$ & $-4,4$ & 0,0 & $-5,5$ & $-4,6$ & $-1,0$ \\
\hline & $\mathrm{S} 3$ & $-9,4$ & $-2,8$ & 2,1 & $-8,0$ & $-3,6$ & 1,0 \\
\hline \multirow{2}{*}{ Rzepak ozimy } & $\mathrm{S} 2$ & $3,9^{*}$ & $2,7 *$ & $2,1^{*}$ & $5,0^{*}$ & $3,0^{*}$ & $2,3 *$ \\
\hline & S3 & $6,6^{*}$ & $6,1^{*}$ & $6,2^{*}$ & $7,6^{*}$ & $6,4^{*}$ & $6,3^{*}$ \\
\hline \multirow{2}{*}{ Pszenica ozima } & $\mathrm{S} 2$ & $-16,2^{*}$ & $-8,2 *$ & $-5,5^{*}$ & $-17,3^{*}$ & $-17,3^{*}$ & $-5,2 *$ \\
\hline & $\mathrm{S} 3$ & $-16,7^{*}$ & $-9,7^{*}$ & $-10,6^{*}$ & $-18,0^{*}$ & $-18,0^{*}$ & $-11,2 *$ \\
\hline
\end{tabular}

Źródło: badania własne; * różnice istotne statystycznie między scenariuszami.

Zmiany klimatu przyczyniły się również do istotnego statystycznie wzrostu przewidywanych plonów rzepaku (tab. 2). Przyrosty plonów w tej uprawie będą zawierały 
się w zakresie 2,1-7,6\%, co nie potwierdziło danych literaturowych dotyczących spadków plonów dla Polski od 0 do $-20 \%$ (Webber i in., 2015).

Pszenica ozima zareagowała istotnymi spadkami plonów na zmiany klimatu (tab. 2). Były one największe na glebie lekkiej, jednakże dla wszystkich gleb przekraczały maksymalne spadki 5\% prognozowane dla Polski (Webber i in., 2015).

Różnice w plonach jęczmienia były nieistotne w poszczególnych scenariuszach zmian klimatu, co jest zgodne z danymi literaturowymi (Knox i in., 2016).

W okresie S1 NUE we wszystkich uprawach wahało się w granicach $60,0-98,5 \%$ (tab. 3). Największe jego wartości notowano dla jęczmienia jarego 94,0-98,5\%.

Tabela 3. Efektywność wykorzystywania azotu (NUE) w latach 1991-2010 (S1)

Table 3. Effectiveness of nitrogen use (NUE) in 1991-2010 (S1)

\begin{tabular}{|c|c|c|c|c|c|c|}
\hline \multirow{3}{*}{ Uprawa } & \multicolumn{6}{|c|}{ NUE (\%) } \\
\hline & \multicolumn{3}{|c|}{ Mocznik } & \multicolumn{3}{|c|}{ Saletra amonowa } \\
\hline & $\mathrm{L}$ & Ś & $\mathrm{C}$ & $\mathrm{L}$ & Ś & $\mathrm{C}$ \\
\hline Kukurydza & 60,0 & 74,0 & 80,5 & 60,5 & 74,0 & 80,5 \\
\hline Jęczmień jary & 98,5 & 95,5 & 94,0 & 97,0 & 95,0 & 96,0 \\
\hline Rzepak ozimy & 70,0 & 71,5 & 71,0 & 69,5 & 71,0 & 73,0 \\
\hline Pszenica ozima & 84,5 & 87,0 & 87,0 & 83,5 & 87,0 & 88,0 \\
\hline
\end{tabular}

Źródło: badania własne.

Według literatury pożądana wartość NUE, gwarantująca dopuszczalne straty azotu, zawiera się w przedziale 50-90\% (EU Nitrogen Expert Panel, 2015). W omawianym eksperymencie symulacyjnym wszystkie wartości NUE były większe od 50\%. Wartości NUE dla jęczmienia jarego były większe od $90 \%$, co oznacza, że dawka azotu $90 \mathrm{~kg} \mathrm{~N}$ ha $^{-1}$ była zbyt mała, a to powodowało, iż rośliny wykorzystywały azot z rezerwy glebowej (EU Nitrogen Expert Panel, 2015). Stosowanie za małych dawek może prowadzić do zubażania gleby w azot.

Tabela 4. Przyrosty efektywności wykorzystywania azotu (NUE) w latach 2011-2030 (S2) oraz 2031-2050 (S3)

Table 4. Increases in the efficiency of nitrogen utilization (NUE) in 2011-2030 (S2) and 2031-2050 (S3)

\begin{tabular}{|c|c|c|c|c|c|c|c|}
\hline \multirow{3}{*}{ Uprawa } & \multirow{3}{*}{ Scenariusz } & \multicolumn{6}{|c|}{ Przyrosty NUE (\%) } \\
\hline & & \multicolumn{3}{|c|}{ Mocznik } & \multicolumn{3}{|c|}{ Saletra amonowa } \\
\hline & & $\mathrm{L}$ & $\dot{S}$ & $\mathrm{C}$ & $\mathrm{L}$ & $\dot{S}$ & $\mathrm{C}$ \\
\hline \multirow{2}{*}{ Kukurydza } & $\mathrm{S} 2$ & $14,5^{*}$ & $10,8^{*}$ & $2,5^{*}$ & $14,5^{*}$ & $10,1^{*}$ & $2,5^{*}$ \\
\hline & $\mathrm{S} 3$ & $17,0^{*}$ & $10,8^{*}$ & $2,5^{*}$ & $15,5^{*}$ & $10,8^{*}$ & $2,5^{*}$ \\
\hline \multirow{2}{*}{ Jęczmień jary } & $\mathrm{S} 2$ & $-13,0 *$ & $-7,9^{*}$ & $-3,0$ & $-12,4 *$ & $-8,4^{*}$ & $-4,5$ \\
\hline & $\mathrm{S} 3$ & $-16,5^{*}$ & $-9,4^{*}$ & $-4,0$ & $-16,5^{*}$ & $-9,5^{*}$ & $-4,5$ \\
\hline \multirow{2}{*}{ Rzepak ozimy } & $\mathrm{S} 2$ & $-1,0$ & $-1,0 *$ & 0,0 & 0,0 & 0,0 & $-0,5^{*}$ \\
\hline & $\mathrm{S} 3$ & 0,0 & $1,0 *$ & 1,0 & 1,0 & 1,4 & $1,0^{*}$ \\
\hline \multirow{2}{*}{ Pszenica ozima } & $\mathrm{S} 2$ & $-20,0 *$ & $-8,0^{*}$ & $-3,0^{*}$ & $-21,6$ & $-8,6^{*}$ & $-4,0 *$ \\
\hline & $\mathrm{S} 3$ & $-17,5^{*}$ & $-12,6^{*}$ & $-10,0^{*}$ & $-18,6$ & $-12,6^{*}$ & $-4,0 *$ \\
\hline
\end{tabular}

Źródło: badania własne.

Przewidywane zmiany klimatu przyczyniły się do zwiększenia wartości NUE w przypadku kukurydzy (tab. 4). Wzrosty były największe na glebach lekkich, a mniejsze 
na średnich i najmniejsze na ciężkich. Stwierdzone wzrosty nie doprowadziłyby w tej uprawie do przekroczenia górnej wartości pożądanego NUE $=90 \%$ (EU Nitrogen Expert Panel, 2015). Oznacza to, że dawka $140 \mathrm{~kg} \mathrm{~N}^{-1}$ wniesiona pod kukurydzę mogłaby być stosowana efektywnie również w przyszłości. To samo można stwierdzić dla dawki $90 \mathrm{~kg}$ $\mathrm{N}$ ha ${ }^{-1}$ stosowanej pod jęczmień. Efektywność wykorzystania tej dawki zmalała w scenariuszach S2 i S3, ale NUE było, z wyjątkiem gleb ciężkich, mniejsze od górnej dopuszczalnej wartości 90\% (EU Nitrogen Expert Panel, 2015). Zmiany klimatu spowodować mogą również obniżenie efektywności wykorzystywania azotu przez pszenicę ozima, znaczne zwłaszcza na glebach lekkich (tab. 4). Obniżenie dawki $120 \mathrm{~kg} \mathrm{~N}^{-1}$ nie będzie jednak w przyszłości konieczne, nawet na glebach lekkich, ponieważ przewiduje się, że NUE będzie większe od 50\% (EU Nitrogen Expert Panel, 2015). Zmiany w NUE w przypadku rzepaku mogą być nieznaczne.

Stosunkowo duże wartości NUE dla omawianych roślin (tab. 3) oraz umiarkowane ich zmiany wskutek zmian klimatu (tab. 4) sugeruja, że straty azotu w eksperymencie symulacyjnym będą stosunkowo małe.

Sumy wymywania i spływu powierzchniowego azotu były największe na glebach lekkich i malały dość systematycznie w pozostałych kategoriach agronomicznych gleb (tab. 5). Największe straty azotu notowano dla roślin jarych (kukurydzy i jęczmienia), mniejsze dla roślin ozimych (pszenicy i rzepaku). Wielkości tych strat wahały się dla wszystkich badanych roślin w granicach 5-18\% zastosowanej dawki azotu ze wszystkich źródeł i były mniejsze od wartości 30\%, domyślnie przyjmowanej przez IPCC (2001). Wielkości strat różnicowały w niewielkim stopniu formy zastosowanego azotu.

Tabela 5. Wymywanie i spływ powierzchniowy azotu w latach 1991-2010 (S1)

Table 5. Nitrogen leaching and runoff in 1991-2010 (S1)

\begin{tabular}{|c|c|c|c|c|c|c|}
\hline \multirow{3}{*}{ Uprawa } & \multicolumn{6}{|c|}{$\operatorname{Azot}\left(\mathrm{kg} \mathrm{ha}^{-1}\right)$} \\
\hline & \multicolumn{3}{|c|}{ Mocznik } & \multicolumn{3}{|c|}{ Saletra amonowa } \\
\hline & $\mathrm{L}$ & Ś & $\mathrm{C}$ & $\mathrm{L}$ & $\dot{S}$ & $\mathrm{C}$ \\
\hline Kukurydza & 18,2 & 13,7 & 10,0 & 19,3 & 14,3 & 10,9 \\
\hline Jęczmień jary & 16,5 & 11,2 & 9,6 & 16,1 & 12,2 & 10,7 \\
\hline Rzepak ozimy & 11,3 & 11,0 & 12,2 & 13,4 & 12,8 & 12,8 \\
\hline Pszenica ozima & 7,7 & 6,1 & 5,1 & 8,0 & 6,1 & 5,4 \\
\hline
\end{tabular}

Źródło: badania własne.

Prognozowane zmiany klimatu powodowały istotne zwiększenie ilości azotu wymywanego i zmywanego w zasadzie jedynie w przypadku kukurydzy (tab. 6). Straty azotu w tej uprawie rosły od gleb lekkich do gleb ciężkich, bardzo dynamicznie zwłaszcza w S3. W przypadku innych roślin zmiany strat azotu były nieistotne $\mathrm{z}$ wyjątkiem jęczmienia jarego nawożonego mocznikiem i uprawianego na glebach ciężkich oraz rzepaku na glebach średnich. 
Tabela 6. Przyrosty wymywania i spływu powierzchniowego azotu w latach 2011-2030 (S2) oraz 2031-2050 (S3)

Table 6. Increases in leaching and surface runoff of nitrogen in 2011-2030 (S2) and 2031-2050 (S3)

\begin{tabular}{|c|c|c|c|c|c|c|c|}
\hline \multirow{3}{*}{ Uprawa } & \multirow{3}{*}{ Scenariusz } & \multicolumn{6}{|c|}{ Przyrosty azotu (\%) } \\
\hline & & \multicolumn{3}{|c|}{ Mocznik } & \multicolumn{3}{|c|}{ Saletra amonowa } \\
\hline & & $\mathrm{L}$ & Ś & $\mathrm{C}$ & $\mathrm{L}$ & Ś & $\mathrm{C}$ \\
\hline \multirow{2}{*}{ Kukurydza } & S2 & $10,3 *$ & 17,6 & $56,4 *$ & $4,2 *$ & $16,8^{*}$ & $57,1^{*}$ \\
\hline & S3 & $37,5^{*}$ & 56,2 & $151,9 *$ & $46,2 *$ & $79,7 *$ & $166,8^{*}$ \\
\hline \multirow{2}{*}{ Jęczmień jary } & S2 & $-2,7$ & 24,1 & $46,4 *$ & $-3,0$ & 15,2 & 35,1 \\
\hline & S3 & $-14,1$ & 22,7 & $14,0^{*}$ & $-9,8$ & 12,3 & 14,7 \\
\hline \multirow{2}{*}{ Rzepak ozimy } & S2 & 19,7 & $22,2 *$ & 15,3 & 4,4 & 11,8 & 11,8 \\
\hline & S3 & 13,3 & $7,4^{*}$ & $-1,0$ & $-4,7$ & $-6,7$ & $-6,7$ \\
\hline \multirow{2}{*}{ Pszenica ozima } & $\mathrm{S} 2$ & 42,6 & $-10,1$ & 3,9 & 38,1 & $-8,2$ & $-3,4$ \\
\hline & S3 & 32,0 & 2,3 & 1,6 & 22,2 & 4,4 & $-2,9$ \\
\hline
\end{tabular}

Źródło: badania własne.

Emisja $\mathrm{N}_{2} \mathrm{O}$ była wielokrotnie większa $\mathrm{w}$ uprawie kukurydzy niż dla innych roślin (tab. 7). W przypadku wszystkich roślin nie zależała ona od kategorii agronomicznych gleb.

Tabela 7. Emisja podtlenku azotu $\left(\mathrm{N}_{2} \mathrm{O}\right)$ w latach w 1991-2010 (S1)

Table 7. Nitrous oxide $\left(\mathrm{N}_{2} \mathrm{O}\right)$ emissions in years 1991-2010 (S1)

\begin{tabular}{|c|c|c|c|c|c|c|}
\hline \multirow{3}{*}{ Uprawa } & \multicolumn{6}{|c|}{$\mathrm{N}_{2} \mathrm{O}-\mathrm{N}\left(\mathrm{kg} \mathrm{ha}^{-1}\right)$} \\
\hline & \multicolumn{3}{|c|}{ Mocznik } & \multicolumn{3}{|c|}{ Saletra amonowa } \\
\hline & $\mathrm{L}$ & Ś & $\mathrm{C}$ & $\mathrm{L}$ & Ś & $\mathrm{C}$ \\
\hline Kukurydza & 0,8 & 0,8 & 0,8 & 0,6 & 0,7 & 0,8 \\
\hline Jęczmień jary & 0,2 & 0,2 & 0,2 & 0,2 & 0,2 & 0,2 \\
\hline Rzepak ozimy & 0,1 & 0,1 & 0,2 & 0,1 & 0,1 & 0,2 \\
\hline Pszenica ozima & 0,1 & 0,1 & 0,2 & 0,1 & 0,1 & 0,1 \\
\hline
\end{tabular}

Źródło: badania własne.

Tabela 8. Przyrosty emisji podtlenku azotu w latach 2011-2030 (S2) oraz 2031-2050 (S3)

Table 8. Increases in nitrous oxide emissions in the years 2011-2030 (S2) and 2031-2050 (S3)

\begin{tabular}{|c|c|c|c|c|c|c|c|}
\hline \multirow{3}{*}{ Uprawa } & \multirow{3}{*}{ Scenariusz } & \multicolumn{6}{|c|}{ Przyrosty $\mathrm{N}_{2} \mathrm{O}-\mathrm{N}(\%)$} \\
\hline & & \multicolumn{3}{|c|}{ Mocznik } & \multicolumn{3}{|c|}{ Saletra amonowa } \\
\hline & & $\mathrm{L}$ & $\dot{S}$ & $\mathrm{C}$ & $\mathrm{L}$ & Ś & $\mathrm{C}$ \\
\hline \multirow{2}{*}{ Kukurydza } & $\mathrm{S} 2$ & $-22,9$ & $21,9 *$ & $16,0^{*}$ & $-1,0$ & $18,1^{*}$ & $8,0^{*}$ \\
\hline & $\mathrm{S} 3$ & $-4,8$ & $37,5^{*}$ & $72,8^{*}$ & $-10,1$ & $20,5^{*}$ & $33,0 *$ \\
\hline \multirow{2}{*}{ Jęczmień jary } & $\mathrm{S} 2$ & $-6,2$ & $-8,3$ & 2,4 & $-23,7^{*}$ & $-33,3$ & $-8,7$ \\
\hline & $\mathrm{S} 3$ & $-37,5$ & $-16,6$ & 4,9 & $-52,6^{*}$ & $-33,3$ & $-4,3$ \\
\hline \multirow{2}{*}{ Rzepak ozimy } & $\mathrm{S} 2$ & $-37,5$ & 4,5 & $14,7^{*}$ & $-28,6^{*}$ & $-5,0$ & 6,2 \\
\hline & $\mathrm{S} 3$ & $-31,2$ & 13,6 & $50,0^{*}$ & $-42,9^{*}$ & $-10,0$ & 12,5 \\
\hline \multirow{2}{*}{ Pszenica ozima } & $\mathrm{S} 2$ & $55,0^{*}$ & $12,5^{*}$ & $-6,7^{*}$ & $55,6^{*}$ & $38,9^{*}$ & $18,2 *$ \\
\hline & $\mathrm{S} 3$ & $160,0 *$ & $170,8^{*}$ & $126,7^{*}$ & $138,9 *$ & $155,6^{*}$ & $181,8^{*}$ \\
\hline
\end{tabular}

Źródło: badania własne. 
Największe istotne przyrosty emisji $\mathrm{N}_{2} \mathrm{O}$ wywoływały przewidywane zmiany klimatu w uprawie pszenicy, zwłaszcza w S3 (tab. 8). Roślina ta charakteryzowała się jednak, podobnie jak rzepak, niskimi emisjami tego gazu w S1 (tab. 7). Istotne przyrosty emisji stwierdzano również w przypadku gleb średnich i ciężkich pod uprawą kukurydzy. Natomiast emisje malały na glebach lekkich pod uprawą kukurydzy, jęczmienia i rzepaku. Wraz ze wzrostem temperatury należało oczekiwać jednolitej tendencji do wzrostu emisji $\mathrm{N}_{2} \mathrm{O}$ (Oertel i in., 2016). Wzrost emisji mógł jednak być hamowany przez stres wodny (Fowler i in., 2009), występujący częściej na glebach lekkich.

Emisje $\mathrm{NH}_{3}$ w S1 były generalnie większe w obiektach nawożonych mocznikiem w porównaniu z saletrą amonową (tab. 9), co jest zgodne ze wskaźnikami emisji z tych nawozów (EMEP/EEA, 2016). Największe były w uprawie pszenicy i rzepaku, a mniejsze w uprawach kukurydzy i jęczmienia. W przypadku wszystkich upraw rosły one od kategorii gleb lekkich do ciężkich.

Tabela 9. Emisja amoniaku $\left(\mathrm{NH}_{3}\right)$ w latach w 1991-2010 (S1)

Table 9. Ammonia $\left(\mathrm{NH}_{3}\right)$ emissions in the years 1991-2010 (S1)

\begin{tabular}{|c|c|c|c|c|c|c|}
\hline \multirow{3}{*}{ Uprawa } & \multicolumn{6}{|c|}{$\mathrm{NH}_{3}-\mathrm{N}\left(\mathrm{kg} \mathrm{ha}^{-1}\right)$} \\
\hline & \multicolumn{3}{|c|}{ Mocznik } & \multicolumn{3}{|c|}{ Saletra amonowa } \\
\hline & $\mathrm{L}$ & Ś & $\mathrm{C}$ & $\mathrm{L}$ & Ś & $\mathrm{C}$ \\
\hline Kukurydza & 0,9 & 1,7 & 7,8 & 0,4 & 0,8 & 3,1 \\
\hline Jęczmień jary & 0,7 & 1,2 & 2,1 & 0,6 & 1,2 & 2,1 \\
\hline Rzepak ozimy & 2,3 & 3,5 & 4,9 & 2,1 & 3,0 & 4,1 \\
\hline Pszenica ozima & 4,1 & 5,8 & 9,5 & 4,1 & 5,7 & 7,5 \\
\hline
\end{tabular}

Źródło: badania własne, obliczenia własne.

Tabela 10. Przyrosty emisji amoniaku w latach 2011-2030 (S2) oraz 2031-2050 (S3)

Table 10. Ammonia emission increases in 2011-2030 (S2) and 2031-2050 (S3)

\begin{tabular}{|c|c|c|c|c|c|c|c|}
\hline \multirow{3}{*}{ Uprawa } & \multirow{3}{*}{ Scenariusz } & \multicolumn{6}{|c|}{ Przyrosty $\mathrm{NH}_{3}-\mathrm{N}(\%)$} \\
\hline & & \multicolumn{3}{|c|}{ Mocznik } & \multicolumn{3}{|c|}{ Saletra amonowa } \\
\hline & & $\mathrm{L}$ & $\dot{S}$ & $\mathrm{C}$ & $\mathrm{L}$ & Ś & $\mathrm{C}$ \\
\hline \multirow{2}{*}{ Kukurydza } & $\mathrm{S} 2$ & $-36,7^{*}$ & $-2,7$ & $-14,0^{*}$ & $41,6^{*}$ & 20,6 & $-8,5^{*}$ \\
\hline & $\mathrm{S} 3$ & $5,1^{*}$ & $-1,0$ & $-16,8^{*}$ & $29,9 *$ & 31,2 & $-2,6^{*}$ \\
\hline \multirow{2}{*}{ Jęczmień jary } & $\mathrm{S} 2$ & $-3,4$ & $-8,9 *$ & $-1,4^{*}$ & 10,1 & $-8,8$ & $-1,0 *$ \\
\hline & $\mathrm{S} 3$ & 22,4 & $19,4^{*}$ & $23,8 *$ & 38,0 & 17,2 & $24,5^{*}$ \\
\hline \multirow{2}{*}{ Rzepak ozimy } & $\mathrm{S} 2$ & 0 & $-1,0$ & 10,4 & 12,6 & 18,3 & 12,8 \\
\hline & $\mathrm{S} 3$ & $-17,3$ & $-20,0$ & $-4,0$ & $-5,5$ & $-6,2$ & 3,7 \\
\hline \multirow{2}{*}{ Pszenica ozima } & $\mathrm{S} 2$ & $-20,2^{*}$ & $-12,6^{*}$ & $-1,7^{*}$ & $-25,3^{*}$ & $-23,1^{*}$ & $-17,8^{*}$ \\
\hline & $\mathrm{S} 3$ & $24,4 *$ & $7,3 *$ & $9,6^{*}$ & $-13,4^{*}$ & $-8,2 *$ & $-7,1 *$ \\
\hline
\end{tabular}

Źródło: badania własne.

Na uwagę zasługuje fakt, że w S2 niemal na wszystkich glebach notowano spadki emisji $\mathrm{NH}_{3} \mathrm{~W}$ polach roślin nawożonych mocznikiem (tab. 10). Oczekiwano raczej, że wzrost temperatury zwiększać będzie emisję tego gazu (Skjøth i Geels, 2013), co odnotowano w S3 tylko w przypadku jęczmienia i pszenicy. Natomiast w przypadku kukurydzy, jęczmienia i rzepaku nawożonych saletrą przeważały dla obu scenariuszy 
wzrosty emisji $\mathrm{NH}_{3}$. Istotnie malały z kolei emisje $\mathrm{NH}_{3}$ w polu pszenicy nawożonym saletrą. Uzyskane wyniki nie są więc całkowicie zgodne z prognozowanym dla Europy Środkowej wzrostem o 0-40\% emisji $\mathrm{NH}_{3}$ wskutek zmian klimatu (Skjøth i Geels, 2013).

\section{Podsumowanie}

Praca miała na celu określenie jak zmiany klimatu wpłyną na plony, efektywność wykorzystywania azotu oraz wymywanie i straty gazowe azotu w zmianowaniu roślin kukurydza na ziarno - jęczmień jary - rzepak ozimy oraz pszenica ozima. Spodziewane zmiany klimatu do 2050 roku przyczynić się mogą w Polsce do: wzrostów plonów kukurydzy na ziarno (6-43\%) i rzepaku ozimego (2-8\%), spadków plonów pszenicy ozimej (-18 do $-5 \%)$ oraz nieistotnych zmian w plonach jęczmienia jarego. Efektywność wykorzystywania azotu wzrośnie w uprawie kukurydzy (2-17\%), zmaleje w uprawach pszenicy ozimej (3-22\%) i jęczmienia jarego (3-17\%) oraz nie ulegnie zmianie w przypadku rzepaku ozimego. Wymywanie i spływ powierzchniowy azotu generalnie wzrośnie statystycznie istotnie jedynie w przypadku kukurydzy (4-167\%). Emisje $\mathrm{N}_{2} \mathrm{O}$ wzrosną w uprawach pszenicy ozimej oraz kukurydzy na glebach średnich i ciężkich lub zmaleją w pozostałych kombinacjach. Emisje $\mathrm{NH}_{3}$ mogą ulegać zarówno wzrostom jak i spadkom. Badania nie potwierdziły tezy, że w zmieniających się warunkach klimatycznych konieczne będzie obniżanie dawek azotu w badanych uprawach.

\section{Literatura}

Billen, G., Lassaletta, L., Garnier, J. (2014). Some conceptual and methodological aspects NUE of agro-food systems. The note at the attention of the EU N-expert panel. Windsor, Sept. 15-16 (manuscript)

EMEP/EEA: EMEP/EEA air pollutant emission inventory guidebook 2016. European Environment Agency, Copenhagen, 2016.

Erisman, J. W., Galloway, J. N., Seitzinger, S., Bleeker, A., Dise, N. B., Petrescu, A. M., Leach, A. M., de Vries, W. (2013). Consequences of human modification of global nitrogen cycle. Philosophical Transactions of the Royal Society B, 368, 20130116.

EU Nitrogen Expert Panel (2015). Nitrogen Use Efficiency (NUE) - an indicator for the utilization of nitrogen in agriculture and food systems. Wageningen University, Alterra, PO Box 47, NL-6700 Wageningen, Netherlands.

Fowler, D., Pilegaard, K., Sutton, M.A., Ambus, P., Raivonen, M., Duyzer, J., Simpson, D., Fagerli, H., Fuzzi, S., Schjoerring, J.K., Granier, C., Neftel, A., Isaksen, I.S.A., Laj, P., Maione, M., Monks, P.S., Burkhardt, J., Daemmgen, U., Neirynck, J., Personne, E., Wichnik-Kruit, R., Butterbach-Bahl, K., Flechard, C., Tuovinen, J.P., Coyle, M., Gerosa, G., Loubet, B., Altimir, N., Gruenhage, L., Ammann, C., Cieslik, S., Paoletti, E., Mikkelsen, T.N., Ro-Poulsen, H., Cellier, P., Cape, J.N., Horvath, L., Loreto, F., Niinemets, U., Palmer, P.I., Rinne, J., Misztal, P., Nemitz, E., Nilsson, D., Pryor, S., Gallagher, M.W., Vesala, T., Skiba, U., Bruggemann, N., Zechmeister-Boltenstern, S., Williams, J., O’Dowd, C., Facchini, M.C., de Leeuw, G., Flossman, A., Chaumerliac, N., Erisman, J.W. (2009). Atmospheric composition change: ecosystems Atmosphere interactions. Atmospheric Environment, 43(33), 5193-5267.

Galloway, J.N., Townsend, A.R., Erisman, J.W., Bekunda, M., Cai, Z., Freney, J.R., Martinelli, L.A., Saitzinger, S.P., Sutton, M.A. (2008). Transformation of the nitrogen cycle: recent trends, questions, and potential solution. Science, 320, 889-892.

Gilhespy, S. L., Anthony, S., Cardenas, L., Chadwick, D., del Prado, A., Li, C., Misselbrook, T., Rees, R.M., Salas, W., Sanz-Cobena, A., Smith, P., Tilston, E.L., Topp, C.F.E., Vetter, S., Yeluripati, J.B. (2014). First 20 years of DNDC (DeNitrification DeComposition): Model evolution. Ecological Modeling, 292, 51-62.

Giltrap, D. L., Li, C., Saggar, S. (2010). DNDC: A process-based model of greenhouse gas fluxes from agricultural soil. Agriculture, Ecosystems and Environment, 136, 292-300. 
IPCC (2001). Good Practice Guidance and Uncertainty Management in National Greenhouse Gas Inventories. Indirect $\mathrm{N}_{2} \mathrm{O}$ emissions from agriculture.

Knox, J., Daccache, A., Hess, T., Haro, D. (2016). Meta-analysis of climate impacts and uncertainty on crop yields in Europe. Environmental Research Letters, 11, 113004, 1-10.

Lassaletta, L., Billen, G., Grizzetti, B., Anglade, J., Garnier, J. (2014). 50 year trends in nitrogen use efficiency of world cropping systems: the relationship between yield and nitrogen input to cropland. Environment Research Letters, 9, 105011, 1-10.

Leip, A., Marchi, G., Koeble, R., Kempen, M., Britz, W., Li, C. (2008). Linking an economic model for European agriculture with a mechanistic model to estimate nitrogen and carbon losses from arable soils in Europe. Biogeoscience, 5, 73-94.

Leip, A., Marchi ,G., Koeble, R., Kempen, M., Britz ,W., Li, C. (2007). Linking an economic model for European agriculture with a mechanistic model to estimate nitrogen losses from cropland soil in Europe. Biogeosciences Discussions, 4, 2215-2278.

Oertel, C., Matschullat, J., Zurba, K., Zimmermann, F., Erasmi, S. (2016). Greenhouse gas emissions from soils Areview. Chemie der Erde, 76, 327-352.

Skjøth, C. A., Geels C. (2013). The effect of climate and climate change on ammonia emissions in Europe. Atmospheric Chemistry and Physics, 13, 117-128.

Webber, H., Zhao, G., Wolf, J., Britz, W., de Vries, W., Gaiser, T., Hoffmann, H., Ewert, F. (2015). Climate change impacts on European crop yields: Do we need to consider nitrogen limitation? European Journal of Agronomy, 71, 123-134.

\section{Do cytowania / For citation:}

Faber A., Jarosz Z., Król A. (2019). Wpływ zmian klimatu na efektywność wykorzystywania azotu oraz jego straty. Problemy Rolnictwa Światowego, 19(1), 37-46; DOI: 10.22630/PRS.2019.19.1.3

Faber A., Jarosz Z., Król A. (2019). The Impact of Climate Change on the Efficiency of Nitrogen Use and its Losses (in Polish). Problems of World Agriculture, 19(1), 37-46;

DOI: 10.22630/PRS.2019.19.1.3 